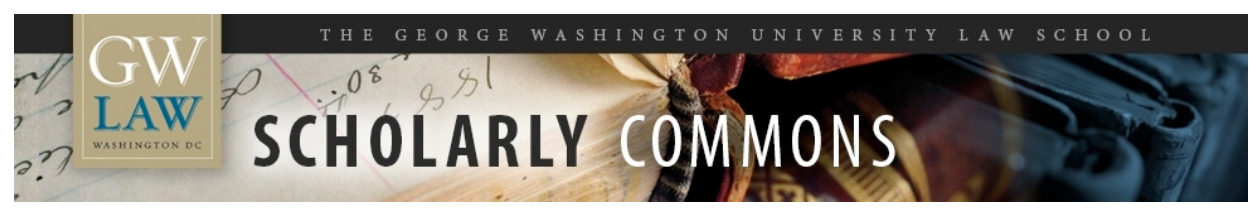

\title{
Removing Property from Intellectual Property and (Intended?) Pernicious Impacts on Innovation and Competition
}

\author{
F. Scott Kieff \\ George Washington University Law School, skieff@law.gwu.edu
}

Follow this and additional works at: https://scholarship.law.gwu.edu/faculty_publications

Part of the Law Commons

\section{Recommended Citation}

Kieff, F. Scott, "Removing Property from Intellectual Property and (Intended?) Pernicious Impacts on Innovation and Competition" (2011). GW Law Faculty Publications \& Other Works. 562.

https://scholarship.law.gwu.edu/faculty_publications/562

This Article is brought to you for free and open access by the Faculty Scholarship at Scholarly Commons. It has been accepted for inclusion in GW Law Faculty Publications \& Other Works by an authorized administrator of Scholarly Commons. For more information, please contact spagel@law.gwu.edu. 
(Working draft - forthcoming in the Supreme Court Economic Review)

\title{
REMOVING Property FROM INTELLECTUAL PROPERTY AND (InTEnded?) PeRnicious Impacts On InNOVATION AND COMPETITION
}

\author{
F. Scott Kieff ${ }^{1 *}$
}

(C) 2011. F. Scott Kieff. All Rights Reserved.

\begin{abstract}
Commentators have poured forth a loud and sustained outcry over the past few years that sees property rule treatment of intellectual property (IP) as a cause of excessive transaction costs, thickets, anticommons, hold-ups, hold-outs, and trolls, which unduly tax and retard innovation, competition, and economic growth. The popular response has been to seek a legislative shift towards some limited use of weaker, liability rule treatment, usually portrayed as "just enough" to

* Professor at the George Washington University Law School and Ray and Louise Knowles Senior Fellow at the Stanford University Hoover Institution. The author gratefully acknowledges financial support for this work from the Northwestern University School of Law Searle Center Project on Innovation, Entrepreneurship, and Economic Growth. The author also gratefully acknowledges intellectual contributions from participants at the 2007 and 2008 Annual Conferences on the Law and Economics of Innovation presented by George Mason University and Microsoft, at the Research Roundtable on the Law \& Economics of Innovation and the Research Symposium on Property Rights Economics and Innovation, both hosted by Northwestern University School of Law's Searle Center, as well as the Annual Meeting of the International Society of New Institutional Economics, and from workshop participants at George Washington University Law School, Washington University School of Law, the Max Planck Institute for the Study of Intellectual Property, and the Munich Intellectual Property Law Center, and appreciates more detailed comments provided by Harold Demsetz, Rebecca Eisenberg, Steve Haber, Troy Paredes, Matt Sag, and Henry Smith. This work is part of the Hoover Task Force on Property Rights, Freedom, and Prosperity, which studies the philosophical, historical, legal, and economic foundations of property rights, as well as the Hoover Project on Commercializing Innovation, which studies the law, economics, and politics of innovation and which is available on-line at www.innovation.hoover.org. Correspondence may be sent to fskieff.91@alum.mit.edu.
\end{abstract}


facilitate transactions in those special cases where the bargaining problems are at their worst and where escape hatches are most needed. This essay is designed to make two contributions. First, it shows how a set of changes in case law over just the past few years have hugely re-shaped the patent system from having several major, and helpful, liability-rule-pressure-release-valves, into a system that is fast becoming almost devoid of significant property rule characteristics, at least for those small entities that would most need property rule protection. The essay then explores some harmful effects of this shift, focusing on the ways liability rule treatment can seriously impede the beneficial deal-making mechanisms that facilitate innovation and competition. The basic intuition behind this bad effect of liability rules is that they seriously frustrate the ability for a market-challenging patentee to attract and hold the constructive attention of a potential contracting party (especially one that is a larger more established party) while preserving the option to terminate the negotiations in favor of striking a deal with a different party. At the same time, liability rules can have an additional bad effect of helping existing competitors to coordinate with each other over ways to keep out new entrants. The essay is designed to contribute to the literature on IP in particular, as well as the broader literatures on property and coordination, by first showing how a seemingly disconnected set of changes to the legal rules impacting a particular legal regime like the patent system can have unintended and sweeping harmful consequences, and then by exploring why within the more middle range of the spectrum between the two poles of property rules and liability rules, a general shift towards the property side may be preferred by those seeking an increase in access and competition.

\section{Table of Contents}

I. Introduction 


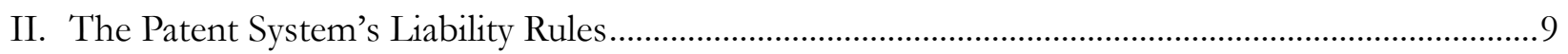

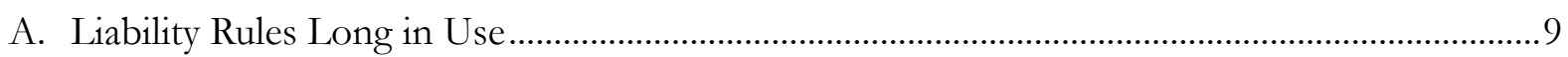

1. Corporate Law, Bankruptcy Law, Litigation..................................................................10

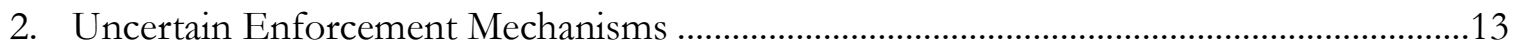

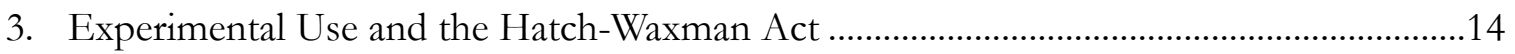

4. Acts of Infringement by or for the Government ............................................................15

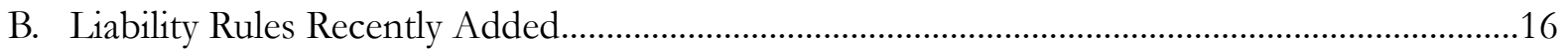

1. Injunctions Eliminated by the eBay Case ............................................................................

2. Enhanced Damages Eliminated by the Seagate Case .............................................................18

3. Expanded Hatch-Waxman Immunity by the Merck Case .....................................................20

4. Increased Uncertainty by KSR, Bilski, and Other Cases...................................................21

III. How Liability Rules Frustrate Deals ...............................................................................................24

A. Direct Impact of Recent Changes from Property to Liability Rules ..........................................25

B. Other Deal Breaking Changes in Rules about Patent Contracts ..............................................28

1. Inability to Settle or Avoid Litigation after the Medimmune Case .......................................28

2. Disincentive to Settle or Avoid Litigation after the Quanta Case..........................................31

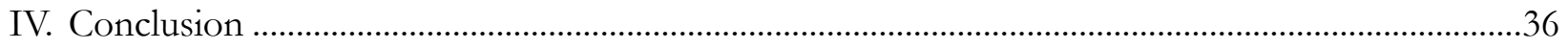

\section{INTRODUCTION}

Getting resources put to use by market actors requires them to interact with each other and with various government actors in various ways, depending on the set of applicable laws, rules, and 
norms (collectively, "institutions"), and their enforcement characteristics. This paper uses the set of analytical tools from the field generally called new institutional economics ("NIE") ${ }^{2}$ to offer a comparative analysis of the various interaction mechanisms that result when the applicable institutions governing private sector entitlements take on the essential features of one of two stylized types that can be seen as property rights "at their best" and "at their worst."3 Property rights are considered to be at their best when they are "easy to predict and find; easy to bundle and divide; structured so that those concerned with the subject matter that the right protects can and should deal directly with the private owner holding the right; and not readily reconfigured by a judge or other government decision-maker," and are at their worst "when they have fixed owners who are not freely able to contract over them[,] and when their contours can be changed either only at the discretion of government actors or too easily at the discretion of government actors, which puts those interested in the subject matter the rights protect in the position of needing to deal with the relevant government decision-makers." ${ }^{4}$

These distinctions boil down to two main areas: transactions and enforcements. The transaction distinctions can be seen as being focused on encouraging market actors to directly transact mostly with each other or mostly with government actors. The enforcement distinctions are

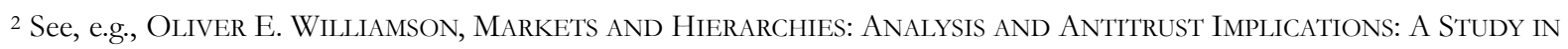
THE ECONOMICS OF INTERNAL ORGANIZATION 1 (1975) (representative early work using the term NIE); Ronald Coase, The New Institutional Economics, 88 AM. ECON. REV. 72 (1998).

${ }^{3}$ See, Stephen H. Haber, et al., On the Importance to Economic Success of Property Rights in Finance and Innovation, 26 WASH U. J. L. \& POL’Y 215 (2008) (discussing examples from finance and innovation of property rights "at their best" and "at their worst," from symposium on "Law \& The New Institutional Economics").

${ }^{4}$ Id. at 216. 
generally labeled by the law and economics and NIE literatures as either "property rules" or "liability rules." Property rules are seen as designed to generally keep an entitlement in the hands of its owner unless the owner consents to use or transfer; and emblematic property rules include injunctions designed to prevent such use or transfer, and enhanced damages designed to deter them. Conversely, liability rules are seen as designed to allow infringement when the owner refuses consent, or when the owner is not even asked, and generally require the non-owner merely to pay, after a lawsuit the property owner elected to bring and maintain, whatever amount of money the property owner proves in court to be attributable to the objectively measured damages caused by the infringement. ${ }^{5}$ While most debates about property and IP focus on questions of how many property rights would be best, generally with owners demanding more property rights and users demanding fewer, this paper focuses attention instead on the different question of how these entitlements are structured, with an eye towards facilitating mechanisms for diverse sets of complementary users of an asset to coordinate with each other over ways to get the asset put to ever higher and better uses while frustrating mechanisms for existing competitors to coordinate with each other over ways to keep out new entrants.

5 See, e.g., Guido Calabresi \& A. Douglas Melamed, Property Rules, Liability Rules, and Inalienability: One View of the Cathedral, 85 HARV. L. REv. 1089, 1092 (1972). Of course, even property rules allow for compelled transfer by a host of mechanisms such as takings accompanied by just compensation, and even property rules contemplate a degree of liability in the form of either enhanced damages or just compensation; and even liability rules discourage taking to the extent of the risk of judgment enforcement and collection for mere objective damages. The difference is both a matter of degree as well as the mechanisms by which such transfers are modulated; yet while the labels are thereby hugely imperfect, they are so well accepted in the law and economics literature that their use easily conveys sufficient meaning to those familiar with these fields. 
In focusing on these mechanisms, this essay does not endeavor to propound any new theory, definition, or even to stretch existing ones. Nor does this essay endeavor to address broader debates about whether predictability in and of itself is always better or worse than flexibility, whether rules are always better or worse than standards. Nor does it argue or even suggest that property rules are always better than liability rules, that more property is always better than less, or that property owners like patentees should always win their lawsuits, or always get more or stronger remedies when they do win. Rather, this essay uses the already-established literature about the types of rules governing legal entitlements and their enforcement characteristics, including in particular those works exploring the paradigmatic features of property rights and property rules in addition to those exploring liability rules and their functional equivalents to highlight some under-explored and pernicious consequences of present trends in both the literature and the cases.

In the vast majority of the intellectual property (IP) literature, property rule treatment of IP is said to cause excessive transaction costs, thickets, anticommons, hold-ups, hold-outs, and trolls, unduly taxing and retarding innovation, competition, and economic growth. The popular view of IP for the past several years has been that property rule treatment is stopping deals from getting done, leaving desired users of IP subject matter unable to engage in sufficient productive activities. For example, the injunction infamously sought against the provider of the BlackBerry service was said to threaten ongoing operations at the upper echelons of the American business, non-profit, and government sectors, which were staffed by VIP's who had come to so depend on the devices that 
the nickname Crackberry was spawned. ${ }^{6}$ To hear some tell it, one might have thought the American Way of Life was at stake and executive levels of our society would shut down if the injunction had been granted.

In response, many commentators suggested trying to solve these important problems of property by only slightly shifting towards some limited use of liability rule treatment or some slight shift towards more reliance on mandating or prohibiting certain terms in contracts. The idea was to facilitate transactions in those targeted cases where the bargaining problems are at their worst and where escape hatches are most needed.

One well-known problem with such a targeted response is that the number of targets is actually not small. Property can face serious pitfalls when the negotiations it would require involve one or both sides being made up of a large number of parties, thereby triggering problems of coordination, free-riding, holdouts, etc., such as when a large number of users would each require permissions from a large number of IP owners. Property's pitfalls also can be serious when the two sides of the negotiation are each individuals, who would still face problems of bilateral monopoly, strategic behavior, and cognitive biases. And mixed sized models raise a mix of both sets of

${ }^{6}$ Blackberry maker Research in Motion is reputed to have strategically targeted such VIP's for free devices as a marketing ploy, recognizing that if the leadership of an organization liked the devices it would both increase the willingness of the organization to invest in the infrastructure needed to support them and at the same time lend a level of prestige to having the devices.

${ }^{7}$ See, e.g., Ian Austen, Bye Bye Blackberry?; A Patent Dispute Threatens To Cut Executives Off, N.Y. Times Dec. 3, 2005, at C1; Jane Spencer \& Jessica E. Vascellaro, Imagining a Day Without BlackBerrys --- Possibility of Shutdown Has Some Users Panicking, Others Dreaming of Freedom, WALL ST. J. Jan. 25, 2006, at D1. 
problems. ${ }^{8}$ But focusing on efforts to determine which of these situations should be targeted first would be a tragic mistake because a more troubling problem has crept up.

This essay argues that just as Jonathan Swift's A Modest Proposal was a less than forthright title for its suggestion that the $18^{\text {th }}$ Century Irish poor sell their children as food for the rich, the calls for seemingly modest and targeted reforms in the patent system over the past few years by innovation's discontents ${ }^{9}$ have not sufficiently acknowledged the important role played by liability rules long present in the patent system or the ways in which the reforms they were pushing would almost remove property rule treatment from this area of IP, almost remove the ability for private actors to contract directly with each other on their own terms, and ultimately shift this area of IP towards a legal regime characterized by property rights at their worst. Part II of this essay begins the discussion by elucidating the several major, and largely helpful, liability-rule-pressure-release-valves that were already built into the patent system and the recent changes that have all but stripped away those few significant property rule characteristics that were remaining. Part III then explores some pernicious effects of this shift by focusing on the ways liability rule treatment can seriously impede the beneficial deal-making mechanisms that facilitate innovation and competition. The basic intuition behind this bad effect of liability rules is that they seriously frustrate the ability for a market-challenging patentee to attract and hold the constructive attention of a potential contracting

\footnotetext{
8 See, e.g., James E. Krier \& Stewart J. Schwab, Property Rules and Liability Rules: The Cathedral in Another Light, 70 N.Y.U. L. REV. 440, 450-51 (1995).

${ }^{9}$ Many of the reform proponents rely on the book by economists Adam Jaffee and Josh Lerner called INNOVATION AND Its Discontents: How Our Broken Patent System is Endangering InNovation And Progress, And What to Do AвоUT IT (2004).
} 
party (especially one that is a larger more established party) while preserving the option to terminate the negotiations in favor of striking a deal with a different party. The discussion also elucidates the way other related and recent shifts in the law governing contracts over patents further frustrate the ability to strike such pro-competitive, pro-innovation helpful deals. Part IV concludes.

\section{The Patent System’s Liability Rules}

Liability rules are no stranger to the patent system. Liability rule treatment is expressly provided in a number of areas within patent law and a number of other areas of patent law have liability rule effect. In addition, patents are enforced only against a backdrop of general civil law, which itself contains a number of tools that effectively keep enforcement of an entitlement like an IP right limited to liability rule treatment in many contexts.

\section{A. Liability Rules Long in Use}

Most property rights systems recognize that an absolute right to exclude backed up by inexpensive, immediate, certain, and powerful enforcement could lead to serious risk that socially productive uses might be prevented or deterred, or that other collateral costs might be realized. For this reason, even most systems of real or personal property have a host of mechanisms for allowing trespass to occur without imposing an immediate death sentence. The patent system also has long recognized that it can be helpful to allow some extent of liability rule treatment, as a tool for facilitating some transactions. While there are a number of these liability rule provisions, they are 
not redundant or identical. Rather, each operates on its own terms and is the product of diverse debate and careful evolution.

\section{Corporate Law, Bankruptcy Law, Litigation}

One of the most important, but also most overlooked, sources of liability rule impact on the patent system are the generally applicable bodies of law relating to the corporate form, bankruptcy, and litigation. Indeed, it has been those often seen as being on the so-called pro-property side of the debates about IP who have pointed out this effect, and even urged its importance to certain types of deal structures. ${ }^{10}$ Because these areas of general commercial law exist largely independent of any one area of entitlement-creating law such as IP, it would be a stretch to say that these areas of law are part of IP in the narrow sense; but they do operate to burnish down the sharp edges one might otherwise imagine would be associated with IP. They also were very much on the mind of the leading champions of the long-operating version of our patent system - the 1952 Patent Act - since those champions - such as Judges Learned Hand and Jerome Frank - were at the same time leading voices in debates about commercial law generally.

While relatively new to the IP literature, the general finance and liability literatures have long focused on the ways the limited liability offered to shareholders under the corporate form ${ }^{11}$ can be

10 See, e.g., F. Scott Kieff, Property Rights and Property Rules for Commercializing Inventions, 85 MinN. L. REV. 697 (2001) (general importance); F. Scott Kieff \& Troy A. Paredes, Engineering a Deal: Toward a Private Ordering Solution to the Anticommons Problem, 47 Boston College L. Rev. 111 (2006) (particular deal structure).

${ }^{11}$ For more on limited liability, see, e.g., Frank H. Easterbrook \& Daniel R. Fischel, Limited Liability and the Corporation, 52 U. CHI. L. REv. 89, 105-06 (1985); Timothy P. Glynn, Beyond "Unlimiting”' Shareholder Liability: Vicarious Tort Liability for Corporate 
combined with the ability to seek protection from the bankruptcy laws to allow for a number of socalled judgment-proofing strategies such as sale-leasebacks, doing business through subsidiaries, franchising, off-shore asset sequestration, secured debt, and traditional asset securitization, that may each have the effect of eliminating legal liability. ${ }^{12}$ These techniques are equally available against

Officers, 57 VAND. L. REV. 329 (2004); Joseph A. Grundfest, The Limited Future of Unlimited Liability: A Capital Markets Perspective, 102 Yale L.J. 387 (1992); Paul Halpern et al., An Economic Analysis of Limited Liability in Corporation Law, 30 U. TORONTO L.J. 117 (1980); Henry Hansmann \& Reinier Kraakman, Toward Unlimited Shareholder Liability for Corporate Torts, 100 YALE L.J. 1879 (1991); David W. Leebron, Limited Liability, Tort Victims, and Creditors, 91 Colum. L. Rev. 1565 (1991); Henry G. Manne, Our Two Corporation Systems: Law and Economics, 53 VA. L. REV. 259, 261-65 (1967); Robert B. Thompson, Unpacking Limited Liability: Direct and Vicarious Liability of Corporate Participants for Torts of the Enterprise, 47 VAND. L. REV. 1 (1994). While the focus here is on corporations, limited partners in a limited partnership and members in a limited liability company also enjoy the benefits of limited liability.

12 For a sampling of the literature on judgment proofing, on which this chapter's discussion of the subject builds, see, e.g., Lynn M. LoPucki, The Death of Liability, 106 YaLE L.J. 1 (1996) [hereinafter LoPucki, Death of Liability]; Lynn M. LoPucki, The Essential Structure of Judgment Proofing, 51 STAN. L. REv. 147 (1998) [hereinafter LoPucki, Essential Structure]; Lynn M. LoPucki, The Irrefutable Logic of Judgment Proofing: A Reply to Professor Schwarcz, 52 STAN. L. REv. 55 (1999) [hereinafter LoPucki, Irrefutable Logic]; Lynn M. LoPucki, Virtual Judgment Proofing: A Rejoinder, 107 YALE L.J. 1413 (1998) [hereinafter LoPucki, Virtual Judgment Proofing]; Charles W. Mooney, Jr., Judgment Proofing, Bankruptcy Policy, and the Dark Side of Tort Liability, 52 STAN. L. REV. 73 (1999); Steven L. Schwarcz, Judgment Proofing: A Rejoinder, 52 STAN. L. REV. 77 (1999) [hereinafter Schwarcz, Rejoinder]; Steven L. Schwarcz, The Inherent Irrationality of Judgment Proofing, 52 STAN. L. REV. 1 (1999) [hereinafter Schwarcz, Inherent Irrationality]; Steven Shavell, The Judgment Proof Problem, 6 INT'L REV. OF L. \& ECON. 45 (1986) [hereinafter Shavell, Judgment Proof Problem]; James J. White, Corporate Judgment Proofing: A Response to Lynn LoPucki's The Death of Liability, 107 YALE L.J. 1363 (1998); Steven Shavell, Minimum Asset Requirements and Compulsory Liability Insurance as Solutions to the Judgment-Proof Problem (Harvard, John M. Olin Discussion Paper No. 456, 2004), at http://www.law.harvard.edu/programs/olin_center/papers/pdf/456.pdf [hereinafter Shavell, Minimum Asset Requirements]. 
patent infringement judgments, and indeed many are used by parties anticipating or engaged in patent litigation.

In addition, judgment proofing against tort creditors like patentees can be particularly easy essentially all that need be done is operate within an outrage constraint. ${ }^{13}$ For example, as long as those running the infringing business respect the corporate form and pay themselves non-fraudulent wages and dividends, etc., they will be able to derive a vast amount of money and other benefits from an infringing business before an infringement lawsuit is brought and won and its judgment collected, and then they will be able to keep those gains from getting hauled back into the infringement estate.

An interesting question for further research might be to study why these techniques are not used even more widely. While some have suggested that such fears over the death of formal legal liability are overstated, because, for example, a parent corporation would rationally elect to pay for the debts of its subsidiary out of an interest in preserving goodwill and reputation, some recent decisions to not pay in the cases involving sex abuse charges against the Catholic Church and alleged human rights violations in Nigeria by a subsidiary of Chevron suggest the reputational constraints may not bind. ${ }^{14}$ The bottom line for infringers is that as a practical matter they may not be on the hook, at least not for the full amount, even if they are found to have infringed.

Even when the careful corporate structuring and planning needed to reduce liability have not been taken, the award of liability can be significantly deterred or delayed by the ordinary process of

${ }^{13}$ That is, avoid behavior that is so totally outrageous that it would generate some type of social backlash.

${ }^{14}$ I thank Lynn LoPucki for pointing this out. See also, Lynn M. LoPucki, Toward a Trademark-Based Liability System, 49 UCLA L. REV. 1099, 1131-34, n. 153 (2002). 
civil litigation. Patents are wasting assets in that they only remain in force for up to about 17 years, and for most patents it is not until several years into patent term that the patented technology even becomes commercially significant. Meanwhile, trying a patent case typically takes at least three to five years; and the appeal typically adds another two to three years. If the patent suit is not likely to end before patent expiration, any threat of injunction will significantly decrease if not become a nullity.

Cost also is a significant deterrent. Patent litigation typically costs each side three to five million dollars, although it is not rare for cases to take more than five years and cost each side twenty to thirty million dollars. Much hay is made by commentators about the threat of damages awards in patent cases frequently reaching into the hundreds of millions and sometimes billions of dollars. But regardless of its size, no judgment is likely to be worth more than the amount that can actually be collected and the judgment proofing strategies can keep collections to a minimum. Decisions to pursue litigation have to weigh the certainty of the several million dollars in litigation expenses against the possibility of collecting on a judgment as well as the possibility of the judgment being awarded.

\section{Uncertain Enforcement Mechanisms}

As Ayres and Klemperer point out, uncertainty and delay in the patent system has the same effect as liability rule treatment. ${ }^{15}$ While Ayres and Klemperer were complaining about the large

${ }^{15}$ Ian Ayres \& Paul Klemperer, Limiting Patentees' Market Power Without Reducing Innovation Incentives: The Perverse Benefits of Uncertainty and Non-Injunctive Remedies, 97 MICH. L. REV. 985, 92 (1999) (criticizing the crispness of the present patent system). 
degree of certainty in the system, Lemley and Shapiro explore the many ways in which the system is properly seen as a probabilistic game of great uncertainty. ${ }^{16}$

\section{Experimental Use and the Hatch-Waxman Act}

Some commentators have long suggested that patent law should permit non-commercial, experimental use of a patented invention as an exception to infringement under a so-called experimental use exemption or research use exemption. To the extent this doctrine exists, it was severely limited in the case of Roche $v$. Bolar $^{17}$ in which the court held that limited experimental use by a generic drug company to obtain Food and Drug Administration (FDA) approval for use after the patent expired was an infringing use.

Congress responded to Roche with the enactment of the Hatch-Waxman Act in 1984, which added Section 271(e) to the Patent Act, and which essentially deems activities reasonably related to FDA approval to be non-infringing, so as to streamline FDA approval of so-called Abbreviated New Drug Applications (ANDA's). At the same time, the Act requires the sponsor of the ANDA to make a certification that the drug will not infringe any valid claim and deems the filing of such a certification to be a jurisdictionally-creating act of infringement so that a patentee can bring suit on the patent during the FDA approval process and if victorious, keep the competition from coming to market until after the patent expires. At the same time, the competition is allowed to make progress on obtaining FDA approval before expiration of the patent so that he is ready to come to market soon after expiration. Thus, in the field of biotechnology, the experimental use exception has been

\footnotetext{
16 Mark A. Lemley and Carl Shapiro, Probabilistic Patents, 19 J. ECON. PERSP. 75 (2005).

17733 F.2d 858 (Fed. Cir. 1984).
} 
viewed as rather liberal, but restrained by the mechanisms of the Hatch-Waxman Act; and in other fields of technology the exception is very limited by the holding of Roche, if the exception exists at all.

It makes sense for the research use exemption to be limited because it turns out that most research uses are in effect permitted via a different mechanism than some formal legal rule of excuse or exception. The transaction costs of dealing with a patentee's right to exclude are not carried entirely by those wanting to obtain permission for use. Unlike the copyright system, the patent system does not have criminal liability or statutory damages and so the costs of enforcement for patents are born by the property owner. The presence of these significant enforcement costs and the lack of significant enforcement benefits in many cases, especially those against low value users for whom damages are likely to be low and even high value users who are judgment proof or judgment remote, combine to make it rational for patentees to greatly under-enforce. Importantly, the theory just reviewed is born out by the facts. Empirical studies of the impact patents have had on basic scientists, for example, have shown that very large numbers of low value infringements are routinely allowed for free. ${ }^{18}$

\section{Acts of Infringement by or for the Government}

As demonstrated in the infamous post-9/11 anthrax scare during which the federal government wanted the owner of the patent on Cipro to provide large quantities of the drug at a low price, the federal and state governments have some protection from infringement by the

18 Timothy Caulfield, Robert M. Cook-Deegan, F. Scott Kieff, \& John P. Walsh, Evidence and Anecdotes: An Analysis Of Human Gene Patenting Controversies, 24 NATURe BioTeCH. 1091 (2006). 
doctrine of sovereign immunity. The Federal Government is subject to suit in the United States Court of Claims by a patentee for "his reasonable and entire compensation" 19 but not for an injunction. In the case of Cipro in the post-9/11 anthrax scare, the Government's threat to either make the drug or have it made was enough to get Bayer, the patentee, to drop its price and increase its output. To be sure, decisions to do this are cabined by the political process as well as the constitutional and statutory requirements that the government pay just compensation, but as seen in cases like Kelo, that outrage constraint does not always bind and parties in need of use are welcome to simply ask the government to make the decision to infringe or to arrange for the infringement.

State governments also are immune. The Supreme Court decided that state governments were immune from suit for patent infringement and that Congressional efforts to abrogate that immunity were unconstitutional under the 11 th Amendment. ${ }^{20}$ While state officials likely may be enjoined, ${ }^{21}$ they may not be personally sued for those patent infringements that are properly part of their official acts.

\section{B. Liability Rules Recently Added}

While the patent system had long contained the mix of property and liability rules described above, the mix was radically shifted over the past few years with a slew of high profile cases that

1928 USC \ 1498. This may either be seen as a limited waiver of sovereign immunity or as a statute that assigns jurisdiction for a cause of action that exists as of right to seek just compensation for a taking under the $5^{\text {th }}$ Amendment. Compare Zoltek.

20 See Florida Prepaid Postsecondary Education Expense Board, v. College Savings Bank, 527 U.S. 627 (1999).

${ }^{21}$ Ex Part Young. 
have almost decimated the property rules remaining in the system. These many new, and overlapping, liability rules are each discussed below.

1. Those Injunctions Eliminated by the eBay Case

For a long time, a central part of the value in a patent was the credible threat of an injunction. But the recent Supreme Court decision in eBay may weaken this long-standing practice. ${ }^{22}$ Some see this case as having raised the bar for patentees seeking an injunction after there has been a full adjudication of patent validity and infringement by injecting more discretion in the determination of essentially whether an injunction is in the broadly defined public interest. Others see the case as merely restating the established practice that an injunction should issue once validity and infringement have been decided in court. In the final analysis, the full impact of the eBay case remains an open question for debate. ${ }^{23}$

But in the short term it looks as if even the Federal Circuit is treating the case as making it very hard to get an injunction except if the patentee is a large manufacturing entity. ${ }^{24}$ In October of

22 See eBay Inc. v. MercExchange, LLC, 126 S.Ct. 1837 (2006).

${ }^{23}$ For more on why and how the eBay decision's four-factor test for injunctions should not be read to be such an open ended analysis, see F. Scott Kieff, \& Henry E. Smith, How Not to Invent a Patent Crisis, in ReACting To The Spending SpREE: Policy Changes We Can Afford, Terry L. Anderson and Richard Sousa, eds., Hoover Institution Press, 2009; Stanford Law and Economics Olin Working Paper No. 384; Harvard Public Law Working Paper No. 10-02. Available at SSRN: http://ssrn.com/abstract=1496990, at 68-69.

${ }^{24}$ Even manufacturing entities who are awarded injunctions, like TiVo, may still face uncertainty over the practical impact of such an injunction, depending on what the en banc Federal Circuit does in TiVo, v. Echostar, 376 Fed.Appx. 21 (Fed. Cir. 2010) (order granting petition for rehearing en banc). 
2007 the court issued an opinion in Paice v. Toyota affirming the power of a district court to impose a post verdict "ongoing royalty" on future sales of a product adjudicated to infringe a patent adjudicated to be not invalid after a full trial by sophisticated and well financed defendants. ${ }^{25}$ The court took pains to write that this was merely an "ongoing royalty" and "not a compulsory license" because it did not apply to non-parties to the lawsuit. What the court seems to overlook is that the defendant elected to be a party by electing to infringe and the patentee was compelled to be a party and compelled to accept the royalty, leaving open the suggestion to future parties interested in this and other patents that the season for infringement is open. It's hard to imagine why other large auto manufacturers won't see the deal Toyota got as a green light to infringe.

2. Those Enhanced Damages Eliminated by the Seagate Case

The victorious patentee in an infringement suit is supposed to be awarded at least actual, objective, damages "adequate to compensate for the infringement, but in no event less than a reasonable royalty." ${ }^{26}$ In the past, the patentee also was generally able to receive enhanced damages for willfulness, which is a question of fact to be proven by clear and convincing evidence, and which if found by fact-finder would then leave within the judge's discretion a decision about whether to treble damages and award attorney fees. ${ }^{27}$

\footnotetext{
25 Paice LLC v. Toyota Motor Corp. 504 F.3d 1293 (Fed. Cir. Oct. 18, 2007).

2635 USC $\$ 284$.

2735 USC $\int \$ 284-85$.
} 
However, the ability for patentees to obtain enhanced damages for willfulness may have been significantly curtailed by the Federal Circuit August 2007 decision in Seagate. ${ }^{28}$ In that case, the Federal Circuit seemed to have established a new requirement for proving willful infringement, a showing of "objective recklessness" on the part of the infringer, based on a two step test: (1) the infringer acted despite an objectively high likelihood that its actions infringed a valid patent, treating the infringer's subjective state of mind as irrelevant; and then (2) that the objectively high risk was either known or should have been known to the infringer. ${ }^{29}$ The court took pains to emphasize that "[b]ecause we abandon the affirmative duty of due care, we also reemphasize that there is no affirmative obligation to obtain opinion of counsel." ${ }^{30}$ The court also strongly suggested that a substantial question regarding infringement or validity that is sufficient to avoid a preliminary injunction also is likely sufficient to avoid a willful infringement finding. But because permanent injunctions are likely to be significantly harder to obtain after eBay, the preliminary injunctions contemplated by Seagate are even more unlikely. In addition, because the general substantive uncertainty discussed above, especially when enhanced by the added uncertainty discussed below, is likely to leave most patent infringement cases in a bad position for a preliminary injunction, the new Seagate test probably means that all those cases now are also in a correspondingly bad position for enhanced damages. Put differently, after Seagate, it is hard to imagine a patentee who can win enhanced damages regardless of the notice he gives the defendant.

\footnotetext{
28 See In re Seagate Technology, LLC, 497 F.3d 1360 (Fed. Cir. 2007) (en banc).

${ }^{29}$ Seagate, 497 F.3d at 1371.

${ }^{30} \mathrm{Id}$.
} 


\section{Expanded Hatch-Waxman Immunity by the Merck Case}

The common law research use exemption discussed above seems to have been reaffirmed recently to be extremely narrow in exempting only those uses that are "for amusement, to satisfy idle curiosity, or for strictly philosophical inquiry." ${ }^{31}$ For academic researchers, who do much if not all of their work in furtherance of philosophical inquiry, the legal test in essence allows only for a very limited amount of research to be conducted on patented technologies to confirm whether they work as described in the patent. It does not allow for the user of a patented technology to be legally exempt from infringing simply because their use has to do with research or is for research purposes. The distinction here is between researching with and researching on, which basically distinguishes between a business purpose that would not be exempt and a purely philosophical interest that could be. The bottom line is that only a limited number of uses to genuinely test whether a patented technology works will be good candidates for the common law exemption.

Nevertheless, and despite the clear legislative intent to limit the Hatch-Waxman Act's exemption for infringement, the Supreme Court in the recent Merck case treated the statutory exemption so broadly that the Court gave a free pass from infringement for work relating to preclinical studies of a new drug seeking FDA approval. ${ }^{32}$ A careful reading of the Merck decision would of course not extend its impact beyond the narrow facts of the case. Any other view would not only be an overly strained reading of the opinion; but it also would undercut the important policies of the patent system. But the language of the Merck opinion seems to suggest that the

\footnotetext{
${ }^{31}$ Madey v. Duke University, 307 F.3d 1351 (Fed. Cir. 2002).

${ }^{32}$ Merck KGaA v. Integra Lifesciences I, Ltd., 545 U.S. 193 (2005).
} 
statutory exemption now is not limited only to the development of information for submission to the FDA and that instead Congress "exempted from infringement all uses of patented compounds 'reasonably related' to the process of developing information for submission under any federal law regulating the manufacture, use, or distribution of drugs." ${ }^{\text {,3 }}$ This language seems to cover almost any use by any company that is in some way regulated by the government, and which therefore may reasonably be anticipating submitting data to a regulatory body.

\section{Increased Uncertainty by KSR, Bilski, and Other Cases}

Two key areas of the law allocating or awarding the initial patent entitlement have undergone a dramatic increase in uncertainty in the past year. The first relates to the patent law requirement of nonobviousness and the second relates to the requirement of statutory subject matter.

The April 2007 US Supreme Court decision in KSR is seen by many as having raised the bar for the nonobviousness standard by injecting more discretion into the determination of this central issue for most patent cases. ${ }^{34}$ The central issue presented in KSR is whether expert opinion testimony in court when adopted at the discretion of a federal judge is enough to prove what would have been obvious to a person having ordinary skill in the art of the patentee at the time in history when the patentee made an invention. Patent critics see the KSR case as standing for the proposition that government decision-makers like judges now have increased discretion to pronounce what the prior art teaches; and they applaud that result, hoping to see it applied in court and during initial Patent Office examination. For example, examiners would be able to block patents on the basis of

\footnotetext{
33 Merck, 545 U.S. at 206.

${ }^{34}$ See KSR International Co. v. Teleflex Inc., 127 S. Ct. 1727 (2007).
} 
their own assertions about what the state of the art was at a particular time in history, without having to rely on the factual proof, such as documents and sample products, which has long been required. Others think the case was narrowly decided on its facts and that the relevant inquiry remains an objective determination of precisely what was taught by the particular combination of relevant pieces of prior art. If the case is ready broadly, then it injects a great degree of flexibility into the nonobviousness analysis.

Similarly, the Federal Circuit has just recently issued three opinions that inject a great degree of flexibility and uncertainty into the law of statutory subject matter. The Supreme Court and Federal Circuit formerly treated as patentable subject matter "anything under the sun made by man." ${ }^{35}$ In a case that effectively opened up the field of computer programs to patent protection, the Federal Circuit in banc upheld as directed to statutory subject matter a patent claim on a computer program for printing a smooth curve on a compute screen. ${ }^{36}$ Then, in a case that effectively opened up the field of financial services to patent protection, the court did the same for a patent on a hub-and-spoke mutual fund accounting system, disposing of the so-called algorithm and business method exceptions to patentable subject matter. ${ }^{37}$ Thus, until recently, the touchstone for patentable subject matter had been merely that the claimed invention must cause come concrete and tangible result, and as a result, patentable subject matter itself presents a very low hurdle to patentability.

\footnotetext{
35 Diamond v. Chakrabarty, 447 U.S. 303 (1980). See also Diamond v. Diehr, 450 U.S. 175 (1981).

36 See In re Alappat, 33 F.3d 1526 (Fed. Cir. 1994)(in banc).

${ }^{37}$ State Street Bank \& Trust Co. v. Signature Financial Group, Inc., 149 F.3d 1368 (Fed. Cir. 1999).
} 
This all changed in September 2007, when the court issued its decision in In re Comisky. ${ }^{38}$ This decision seems to limit the scope of the State Street Bank decision by requiring a pure mental process be connected to a machine (e.g., a computer) in order for a claim to recite subject matter that can be patentable. As a result of this decision, patent drafters and inventors of mental processes will be required to combine a particular technology such as a computer with such mental processes for the subject matter to meet the statutory requirement of patentable subject matter. While this seems like an easy decision to draft around, it is strikingly similar to the slippery slope we previously occupied in the 1970's and 1980's during which we effectively made every software patent subject to discretionary review for being too close to a mental step and therefore invalid. Indeed, in a case handed down the same day as Comisky, In re Nuijten, ${ }^{39}$ the Federal Circuit examined the patentability of claims to a digital watermark for a computer data file simply declared it to be not within any patentable subject matter. While some may have thought that Comisky and Nuitjen were outliers, the Federal Circuit's October 30, 2008 in banc decision in Bilski seems to all but fully jettison the approach of cases like State Street Bank in deciding that to be eligible for patent protection the claimed subject matter must either (1) be tied to a particular machine or (2) transform a particular article. ${ }^{40}$ It's difficult to imagine judges or anyone else viewing the precipitous drop in

38499 F.3d 1365 (Fed. Cir., 2007).

39500 F.3d 1346 (Fed. Cir., 2007).

40 In re Bilski, 545 F.3d 943 (Fed. Cir. 2008)(en banc), petition for cert. granted, sub nom, Bilski v. Doll, 129 S.Ct. 2735 (Jun 01 , 2009). Given the oral argument in the case before the Supreme Court, it was likely that the predictable approach of cases like Diehr, Alappat, and State Street Bank was not likely to be embraced by The Court at that time. While The Court's majority opinion in Bilski v. Kappos, 130 S.Ct. 3218 (2010) appeared to leave State Street Bank intact by not only briefly citing that case, the reference was not positive. 130 S.Ct. at 3231 ("nothing in today's opinion should be read as endorsing interpretations of $\int$ 
their own stock accounts caused by the fall 2008 economic collapse as not being a meaningful transformation; and yet the claim at issue in Bilski was directed to a process of managing financial risk of exactly that type. As a result, it looks like the definitional line drawing that will have to be done after Bilski to determine how much of a transformation in risk $^{41}$ or financial value is sufficiently transformative is at least as unpredictable as it was during the period of greatest recent uncertainty in this area - between the Supreme Court's 1972 Benson $^{42}$ and 1981 Diehr decisions. This type of "know it when you see it" decision making by a court re-injects massive uncertainty into the law of patentable subject matter.

While flexibility sounds attractive whether used in these areas or others, it has a serious Achilles Heel. By increasing the discretion of government bureaucrats, flexibility increases uncertainty, not decreases it, and it gives a built-in advantage to large companies with hefty lobbying and litigation budgets. That's a big reason why some big firms want it. And even if certain, it is now certainly much harder to get patents in this area.

\section{How Liability Rules Frustrate DeAls}

A central and underexplored problem with liability rules is that they seriously frustrate the ability for the patentee to attract and hold the constructive attention of a potential contracting party

101 that the Court of Appeals for the Federal Circuit has used in the past," and citing State Street Bank). Treatment in the other opinions was more negative, leaving an overall Section 101 jurisprudence about as uncertain as it was before the Bilski line of cases begasn in the Federal Circuit.

${ }^{41}$ Would you feel you had been meaningfully transformed if you were warned sufficiently in advance to step aside from the freight train fast approaching you from behind?

42 Gottschalk v. Benson, 409 U.S. 63 (1972). 
while preserving the option to terminate the negotiations in favor of striking a deal with a different party. This comparative effectiveness of property rules in achieving these goals is the mechanism by which property rules facilitate both innovation and competition. That is, property rules help get done the deals needed to build the small- and medium-sized business that create new lines of business to compete against existing ones.

\section{A. Direct Impact of Recent Changes from Property to Liability Rules}

Many scholars have focused on the relative overall information costs and transaction costs of liability rules compared with property rules, and the way liability rules tend to overall provide lower compensation than property rules. ${ }^{43}$ In addition, Haddock, McChesney, and Speigel have explored the threat posed by a large number of potential takers in the liability rule setting and its net impact in decreasing ex ante incentives to invest in the underlying entitlement. ${ }^{44}$

43 See, e.g., Richard A. Epstein, A Clear View of The Cathedral: The Dominance of Property Rules, 106 YALE L.J. 2091 (1997) (information costs and transaction costs); Robert P. Merges, Of Property Rules, Coase, and Intellectual Property, 94 CoLUM. L. REV. 2655 (1994) (same); Henry E. Smith, The Language of Property: Form, Context, and Audience, 55 STAN. L. REv. 1005 (2003) (same); Richard R.W. Brooks, The Relative Burden of Determining Property Rules and Liability Rules: Broken Elevators in the Cathedral, 97 Nw. U. L. REv. 267, 268 n.8 (2002) (elucidating analytical framework for assessing “the relative burden (or costs, or difficulty) faced by judges when attempting to determine property rules and liability rules"); Louis Kaplow \& Steven Shavell, Property Rules Versus Liability Rules: An Economic Analysis, 109 HARV. L. REV. 713 (1996) (undercompensation); see also Louis Kaplow \& Steven Shavell, Property Rules Versus Liability Rules: An Economic Analysis, 109 HARV. L. Rev. 713, 732-33 n.61 (1996) (same).

${ }_{44}$ David D. Haddock et al., An Ordinary Economic Rationale for Extraordinary Legal Sanctions, 78 CAL. L. REv. 1, 16-17 (1990); F. Scott Kieff, Property Rights and Property Rules for Commercializing Inventions, 85 MinN. L. REV. 697, 733 (2001). 
Yet, the literature has not devoted much focus to the mechanism by which actual breakdown in bargaining occurs (the "bargain effect" of property rules), let alone to the way the credible threat of exclusion associated with a published patent acts like a beacon in the dark, drawing to itself all those interested in the patented subject matter (a "beacon effect"). Knowing there is a good chance that a court employing a liability rule approach will set a lower price than the IP owner would accept, some potential infringers may first try for a low damage award from the court, rather than consummate a deal up front with the IP owner, and then later make a deal if the court award is too high. The prospect that infringement may be an attractive option to some can decrease the incentives for all others to attempt or consummate a deal up front, thereby weakening both the beacon effect and the bargain effect that are associated with property rules. ${ }^{45}$

The decrease in incentives in part occurs because each potential taker must worry about other potential takers following suit. That is, liability rules for one mean non-exclusive licenses for all.

The problem also is due to the way in which the incentive to consummate a deal is decreased by the availability of the option to get a court to force the deal. A central argument in favor of liability rule treatment is that it is most needed as pressure release for those cases in which one side to a negotiation is acting irrationally or strategically and simply not getting along with the other. But, if the ability to avoid the property rule treatment hinged upon the failure of a deal getting done, then there would be a markedly increased incentive for those wanting to obtain use through court-

\footnotetext{
45 See, F. Scott Kieff, On Coordinating Transactions in Information: A Response to Smith's Delineating Entitlements in Information, 117 Yale L.J. Pocket Part 101 (2007); F. Scott Kieff, Coordination, Property, and Intellectual Property: An Unconventional Approach to Anticompetitive Effects and Downstream Access, 56 EMORY L.J. 327 (2006).
} 
ordered terms to resist striking licensing deals. A legal test that rewards a failure to cooperate would lead to a decrease, rather than an increase in cooperation. ${ }^{46}$ Simply put, instead of the problem being a fear that the patentee is engaging in a hold-out or a hold-up game against the one desiring use, the problem will instead become that the patentee will be unable to hold its potentially bargaining partner in the negotiation, since that partner will instead want to engage in tactics designed to make the patentee act irrationally, such as by engaging in a proverbial Three Stooges poke in the eye, and then run off to simply wait for the court to issue what the Federal Circuit in Paice $v$. Toyota refused to call a compulsory license. ${ }^{47}$

What is more, not only is the patentee unable to hold this party in a negotiation, the patentee is unable to hold-on to the option to end the negotiation and deal with some other user over an exclusive license or assignment. That is, not all deals should get done and liability rule treatment forces them to get done.

What is worse, it appears that in the post eBay world the only party who can count on an injunction will be a large manufacturing entity. Ironically, these are the parties who need the protection of the injunction the least. First off, large players will usually be better able to finance the litigation and so bring a more credible threat to bear against infringers. Second, large players are more likely than small players to be able to keep their potential contract counterparts engaged in a contract relationship without the credible threat of the injunction, relying instead on broader relationships, reputation effects, and bargaining power.

\footnotetext{
${ }^{46} I d$.

${ }^{47}$ See supra note 25 , and accompanying text.
} 


\section{B. Other Deal Breaking Changes in Rules about Patent Contracts}

In addition to the recent shift toward overall liability rule treatment generally frustrating the ability of a patentee get done appropriate deals, another set of recent changes further frustrate that ability for the patentee to even settle or avoid cases. These involve the law governing two areas of contracting over patents, as discussed below.

1. Inability to Settle or Avoid Litigation after the Medimmune Case

Invoking some kind of general and non-statutory public policy against those patents that enjoy a statutory presumption of validity, ${ }^{48}$ but that are likely to be held invalid by a court if adjudicated, the Supreme Court decided in the 1969 Lear case to allow a party to a patent license to contest the validity of the licensed patent even if there is an express promise in the contract license to not raise such a challenge. ${ }^{49}$ The general rule of Lear had been interpreted to require a challenger to do more than simply stop paying the royalties or performing the other obligations under the contract - he must also go so far as to formally challenge the patent's validity. ${ }^{50}$

The balance these cases created essentially gave the licensee the benefit of not being bound to his promise to not challenge, but at the same time saddled the licensee with the obligation to actually walk away from the entire license agreement when challenging the patent. The basic point

4835 U.S.C. $\int 282$.

${ }^{49}$ Lear v. Adkins, 395 U.S. 653 (1969); see also Beckman Instruments, Inc. v. Technical Dev. Corp., 433 F.2d 55 (7th Cir. 1970) (Lear applies to exclusive licensees); Bull v. LogEtronics, Inc., 323 F. Supp. 115 (E.D. Va. 1971) (Lear applies to assignees).

50 See, e.g., Rite-Nail Packaging Corp. v. Berryfast, Inc., 706 F.2d 933 (9th Cir. 1983). 
was that the challenger could renegotiate the entire deal by electing to challenge, but could not selectively hold the patentee to all terms binding the patentee while allowing the licensee to have a shot at renegotiating some decrease in payment or other obligation once patent had been adjudicated invalid.

Concerned that this balance of interests was out of alignment, the January 2007 Supreme Court decision in Medimmune makes it particularly easy for the licensee to bring such a challenge by no longer requiring the licensee to have to go all the way to break the entire license contract itself, instead allowing the licensee to challenge while keeping the patentee bound by the remaining contract terms. ${ }^{51}$ The court in that case held that the patent licensee in that case was "not required, insofar as Article III is concerned, to break or terminate its 1997 license agreement before seeking a declaratory judgment in federal court that the underlying patent is invalid, unenforceable, or not infringed."

Some might think that a contractual work around to this case is the use of an express provision in the contract promising not to challenge the validity of the patent. But the broad public policy articulated in cases like Lear does not on its own terms have a constraint against being read so broadly as to make such a contractual provision against that public policy, and thereby unenforceable as against public policy or unenforceable as pre-empted by a federal policy. In addition, it is not clear what the remedy would be for such a breach. Lear itself prevents an injunction against challenging since Lear allows for a challenge in the face of a non-challenge promise. It also is not clear what the damages would be. Even if the expectation damages were viewed as including the

\footnotetext{
51 See MedImmune, Inc. v. Genentech, Inc., 549 U.S. 118 (2007).
} 
cost of litigation, in most of these cases the central goal of the patentee will be to either keep the licensee bound to all terms or to leave both parties unbound to any terms. It is not at all clear that some damages award could achieve either of these goals even if a court were included to try to award it. For example, some scholars, like Sean O'Connor, have suggested that parties enter into structured deals with stock and stock options in the licensee, to provide the patentee with a functional equivalent to a patent royalty stream. ${ }^{52} \mathrm{~A}$ central shortcoming of approaches like these is the shortcoming the plagues any damages award. Damages don't cover for the many non-price terms that are in patent license agreements - after all, if patent license agreements were only about price they would be a single sentence listing price instead of being many pages in length. But patent license agreements are often very textured contracts having many terms, including price and a host of seemingly esoteric and unique provisions_-such as technical support, field-of-use or territory limitations, grant-backs, cross-licenses, payment schedules, and most-favored-nation provisions.

As a result, it is likely that parties will pursue other contractual work arounds. If maintaining the enforceability of these non-financial clauses is important to contracting parties, then one approach they might adopt is to split their patent licenses deals into two bundles, with one set of deals each being labeled as a simple patent license for a stated price, with the recognition that this one may be avoided through a one-sided challenge as in Medimmune, and the second set being a single deal arranging through a complex relational contract the many other important terms. At least two problems arise with this strategy: it increases the overall social costs of contracting with

52 Sean O’Connor, Using Stock and Stock Options to Minimize Patent Royalty Payment Risks after MedImmune v. Genentech, 3 N.Y.U. J. LAW \& BUS. 381 (2007). 
little social benefit; or the complexity of such sets of deals will be pierced as courts treat them as essentially a single deal subject to the same treatment as in Medimmune.

The bottom line is that the medium and strong readings of Lear and Medimmune suggest that patentee's will always have to recognize that when they give "peace" from litigation by executing a license agreement they will not be able to at the same time gain "peace" from litigation. This substantially reduces incentives to license by removing the central element - mutual and symmetrical "peace" -- from the economics of a licensing transaction. A license is a promise not to sue and those promises are now only enforceable one-way, which means they are of significantly less value to both sides of the deal.

\section{Disincentive to Settle or Avoid Litigation after the Quanta Case}

In June 2008 the Supreme Court issued it's most recent patent decision in Quanta v. LG, , $^{53}$ which involves a patentee's decision to settle out a dispute with one party, Intel, but giving that party a limited license for that party's own use. The contract in that case expressly provided that Intel's customers would not be licensed under the patent and expressly required Intel to give notice to those customers of this lack of license. Those customers were large computer manufacturers on actual notice of this lack of license and yet brought their case to the Supreme Court arguing that the patentee in effect created an improper restrictive covenant running with the computer chips.

It made sense for Intel and the patentee to enter into this limited license because essentially, the patentee and Intel were entering into a blanket settlement of IP cases that bought Intel freedom,

${ }^{53}$ Quanta Computer v. LG Electronics, 128 S.Ct. 2109 (2008). 
but only bought freedom for Intel. Intel needed the freedom because, for example, Intel might otherwise have been guilty of inducing third parties to infringe when it sold its products, computer chips. This settlement made clear that it let Intel free but not Intel's customers, and the price reflected this limited ambition.

The petitioner in the case successfully argued that the so-called first sale doctrine makes the broad unrestricted license required. Under the long established view of this doctrine, a patentee's unrestricted voluntary introduction of a patented article into commerce, such as through a sale, may prevent the patentee from exercising his right to exclude others from the particular article so introduced. For example, a patentee who makes an unrestricted sale of a patented widget may not be able to sue the buyer, or any other downstream user of that particular widget for infringement. After all, the buyer presumably paid the patentee not only for title to the good in the sales sense, but also for permission to use it for its intended purpose. Thus, the first sale doctrine was long viewed safely as a contract-based doctrine that implied into contracts for unrestricted sales of patented articles a term that conveyed some authority to use the article free from a suit for infringement. But this long-established view of the doctrine treated it as merely a default rule, because courts had long recognized that restrictive terms in a sale - such as a sale accompanied by a promise to make only a single use of the patented article - would be enforceable as long as they do not violate some other rule of positive law, is not adhesionary, or unconscionable, etc. ${ }^{54}$

Importantly, in general when you buy something you are not entitled to think that it is free of a patent -- especially if you are a large commercial player. Under the long established view of the 
first sale doctrine it only got triggered if you bought the patented thing from the patentee, because it made sense in that case for you to have thought that you were buying a thing and also a license to use the thing under the patent - that's presumably why you bought it from the patentee rather than from someone else or made it yourself. The key was your reasonable impression as a buyer that you were getting a license. In Quanta, the "buyers" only came to know of Intel's license by reading it, and its text made explicit that only Intel was licensed and not Intel's customers. So, there was on the facts no chance of confusion or mistake or duress etc. Quite the opposite, the buyer had to argue that it was seduced into thinking it was licensed by reading only half the document that seduced it. But that seems to be what the Supreme Court decided.

The Court's decision in the case creates a very strong disincentive to settle a case with any one of the many possible infringers in a market. In view of Quanta, any such settlement is now likely to create some kind of license that could be used to launder all other members of the market. As a result, now settlements may have to be with all at a very high price or with none at all.

A range of structured work-arounds may be attempted after Quanta. Each is discussed below and each may be used alone or in combination with the others. But it is not clear whether any of these will be viewed by courts as being consistent with the broad policy statements made in the Quanta opinion. As a result, and as with attempted work arounds for Medimmune, costs of transacting may increase with little benefit, or the attempted fixes may not even work.

The first attempted fix for Quanta is to make clear that the contract being struck is not, in fact, a patent license. Under this approach, the contract should be labeled as a "restricted and limited agreement to release and not sue." All operative clauses should avoid using the word "license" and its variants and instead use variants of the phrase "restricted and limited agreement to 
release and not sue." To the extent that The Court in Quanta is making broad statements about federal patent policy that impact patent licenses, structuring the deal in this suggested fashion places the deal more outside of the reach of that potential policy of federal patent law. Indeed, this approach also places the deal more within the zone of more favored policy of resolving and avoiding federal court litigation, a policy that is federal itself and so is not merely a matter of state contract law of the type that might be preempted by a potentially conflicting federal patent policy.

The second attempted fix, which assumes the parties strongly prefer labeling their contract a patent license, is to make clear in all references to the license in that contract, especially in the grant clause, that the license is, itself, on its own terms, restricted. The Quanta case and many patent first sale cases focus a great deal on there being an "unrestricted sale." To increase the chance that the parties take their license out of the reach of those cases the parties should be sure to explicitly restrict all licenses and all sales of patented subject matter. That is, the license should be restricted to whatever limits they want to place on it and in addition it should be restricted to reaching only those sales that are themselves made in a way that is expressly restricted.

The third strategy uses two guidelines that come from the Quanta decision itself. The Court in Quanta stated that so-called "patent exhaustion" occurs when: (1) the only "reasonable and intended use" of the component product sold was to practice the combination or method patent; and (2) the component product sold "embodies essential features" of the combination or method patent. As a result, the more the parties take a range steps in the contract to make clear that the parties to not intend to have certain uses meet both of these tests, the more a court may determine those uses are not covered by the reach of "patent exhaustion." For example, if the contract can make clear what uses are "intended" and what uses are not, the more likely a later court will 
determine that "patent exhaustion" is not triggered. The central concern with this approach is that some courts may make their own determination of what use is reasonable and extend patent exhaustion to reach all of those uses regardless of the language in the contract to the contrary.

The fourth strategy is to make sure that any restrictions or limits or obligations etc. that are associated with any grant are expressly structured as conditions rather than as contractual obligations. This is because if a contracting party does not meet all of its contractual obligations then the only recourse is a suit for breach for which the remedy will be at most expectation damages. Moreover, only those breaches that are material will give rise to a cause of action, since substantial performance is all that many courts require. In contrast, if a material condition is not met then the benefit the party seeks from the patentee is not itself triggered. The recourse for the patentee is more automatic and complete - the permission, or the license, or the promise not to sue, etc. would not be given.

Only further empirical research will let us know which, if any, of these several contractual work-arounds to Medimmune and Quanta are tried, whether they work, etc. But one effect that is likely to evolve is that the most stable patent licenses after these cases will be those cross licensing large portfolios, because only those types of licenses avoid the need for both precise evaluation and firm commitment for each patent - what holds together deals of that type is fear of mutually assured destruction, or symmetrical threat of large numbers of litigations. If this prediction is correct, then the outcome will be a web of contractual arrangements between large players to the exclusion of market entrants, which is decidedly anticompetitive. 


\section{CONCLUSION}

The many recent changes to the patent system through court decisions over the years have synergistically interacted with each other to leave the patent system seriously lacking in property rules, especially for small market entrants trying to sue or license larger more established market participants, and except perhaps for large established participants when suing market entrants. The stated purpose of stripping away this protection was to facilitate bargaining and avoid hold out and hold up effects. But while the property literature has long recognized and endeavored to mitigate the problems of property rules, we now face the problems of liability rules without the aid of a developed set of tools for mitigating them.

There are several basic intuitions underlying the problem caused by using liability rules only. First, while liability rules force deals, some deals just shouldn't get done. Second, a rule that allows for liability rule intervention in those cases where the parties disagree on deal terms encourages disagreement and frustrates transactions. Third, and most importantly, liability rules make it significantly more difficult for owners of IP rights like patents to attract and hold the constructive attention of a potential contracting party (can't hold-in the counterparty), and eliminate the patentee's option to terminate the negotiations in favor of striking a deal with a different party (can't hold-on to option). This problem hits small firms worse than large firms because large firms have an easier time keeping their contracting parties tethered to deals through various devices such as bargaining power, access to resources needed to finance litigation and its threat, and reputation effects. Fourth, liability rules actually help large established firms to coordinate with each other in an anticompetitive fashion to keep out market entrants. 
Worse yet, the problems that have recently been introduced into the patent system through the removal of property rule treatment are only compounded by shifts in other rules governing patent contracts. Even when patent deals are struck they no longer seem to be enforced post Medimmune. Alternatively, the licenses that a patentee does grant one party may be granted to all third party buyers after Quanta, thereby creating a strong disincentive to even attempt to strike deals through patent settlements and other licenses. And the only firms well positioned to mitigate the transaction inhibiting effects of these new contract law rules are those large firms that can use a strategy of swapping large portfolios of patent licenses, thereby further enhancing their ability to coordinate with each other to keep out market challengers.

The bottom line is that under the patent system newly created by the courts, it is very hard to see how patents can have significant positive effect in facilitating the coordination and contracting that can lead to increased competition and access. Instead, the prevalence of liability enforcement rules and mandatory and prohibitory contracting rules may actually be causing a substantial negative impact, the keiretsu effect of facilitating collusive anticompetitive coordination among large established market participants. ${ }^{55}$ While this essay does not endeavor to celebrate the original version of our patent system that was created by the Framers of our Constitution, or to speak out against progress or even change, the problems it explores, which are seriously under-explored, if not totally ignored, by most of the contemporary literature, combine to make the present system a strong candidate for change in the opposite direction called for by most other commentators.

\footnotetext{
55 See, F. Scott Kieff, On Coordinating Transactions in Information: A Response to Smith's Delineating Entitlements in Information, 117 Yale L.J. Pocket Part 101 (2007), F. Scott Kieff, Coordination, Property, and Intellectual Property: An Unconventional Approach to Anticompetitive Effects and Downstream Access, 56 EMORY L.J. 327 (2006).
} 
Nevertheless, it is essential to keep in mind that even the present system, with its increased access to liability rules, is still a far cry from a full compulsory licensing system that some might advocate. The essential distinction here is between the compulsory licensing that involves a plea to the government for an exemption accompanied by some very modest payment, often from the government itself, and each of the detailed mechanisms that a party seeking to use a patented invention must employ to even take advantage of the various liability rules discussed in this essay. At a minimum, this distinction should be preserved to prevent the US from becoming a compulsory licensing regime.

$$
* * * * *
$$

